Marcos Antonio Fernandez 1,2

Aricelso Maia Limaverde 1

Italo Braga de Castro ${ }^{3}$

Ana Cristina Martins Almeida 1

Angela de Luca Rebello Wagener 1

\section{Occurrence of imposex in Thais haemastoma: possible evidence of environmental contamination derived from organotin compounds in Rio de Janeiro and Fortaleza, Brazil}

\author{
Ocorrência de imposex em Thais haemastoma: \\ possíveis evidências de contaminação ambiental \\ por compostos organotínicos no Rio de Janeiro \\ e em Fortaleza, Brasil
}

1 Departamento de Química, Pontifícia Universidade Católica do Rio de Janeiro. Rua Marquês de São Vicente 225, Rio de Janeiro, RJ 22453-900, Brasil.

2 Departamento de Oceanografia, Universidade do Estado do Rio de Janeiro. Rua São Francisco Xavier

524, sala $4018 \mathrm{E}$,

Rio de Janeiro, $R J$ 20550-013, Brasil. hallfz@uerj.br

3 Departamento de Biologia Laboratório de Malacologia, Universidade Federal do Ceará. Av. Humberto Monte s/n, Campus do Pici, Bloco 909, Fortaleza, CE 60000-000, Brasil.

\begin{abstract}
There are indications that the widespread use of organotin compounds (TBT and TPT) as antifoulings, as stabilizers in plastic and as pesticides, has severely affected several species of marine organisms. The most striking effect of TBT and TPT as hormonal disruptors is the development of male organs in females of gastropods, currently denominated imposex. This syndrome can lead to the sterilization and death of affected organisms. The present work gives an overview of the present state of knowledge on imposex occurrence and reports results of a survey conducted in Guanabara Bay, Rio de Janeiro and in several sites along the coast of Fortaleza, Ceará State. Different stages of imposex development were verified in this survey, however, the most prominent levels appeared associated to known spot sources of TBT and TPT.
\end{abstract}

Key words Organotin Compounds; Thais haemastoma; Imposex; Endocrine Disruptors

Resumo Existem evidências de que a utilização amplamente disseminada de compostos organoestânicos (TBT e TPT) como antiincrustantes, estabilizadores em plásticos e como pesticidas tenha afetado severamente diversas espécies de organismos marinhos. O mais característico efeito do TBT e do TPT como desreguladores endócrinos é o desenvolvimento de caracteres sexuais masculinos em fêmeas de gastrópodos, conhecido como imposex. Esta síndrome pode levar à esterelização e morte dos organismos afetados. O presente trabalho apresenta uma vista geral ao estado atual do conhecimento sobre a ocorrência do imposex, e reporta os resultados de um estudo conduzido na Baía de Guanabara, Rio de Janeiro, e ao longo da costa de Fortaleza, no Ceará. Diferentes estágios de desenvolvimento do imposex foram verificados neste estudo, os mais proeminentes parecendo associados às fontes pontuais locais conhecidas de TBT e TPT.

Palavras-chave Compostos Orgânicos de Estanho; Thais haemastoma; Imposex; Desreguladores Endócrinos 


\section{Introduction}

Organotin compounds have been in use since the 1960s. Due to its powerful antifouling effect tributyltin (TBT) has been utilized as an additive in paintings applied to ships, fishing nets, marine installations and cooling systems based on seawater (Bacci \& Gaggi, 1989; Fent, 1996; Horiguchi et al., 1994; Short \& Thrower, 1986). Triphenyltin (TPT) has been used in association with TBT in antifouling paintings but is also effectively applied as acaricide and fungicide in agriculture and for wood preservation (Favoreto, 2000; Fent, 1996; Mensink et al., 1997). Di-substituted organotin compounds are used as plastic stabilizers in PVC production and as catalysts in some industrial processes.

Environmental problems derived from the use of organotin compounds as antifouling agents were first reported by the end of the 1970s after a sharp decline in oyster production was observed in the Basin d'Arcachon, France (Alzieu et al., 1986, 1989). The main biological alterations initially ascribed to the widespread use of organotins were balling in oysters (Alzieu et al., 1986, 1989; Axiak et al., 1995; Dyrinda, 1992), death of mollusk larvae (Horigushi et al., 1998) and imposition of male sexual characteristics to females of gastropods (Ellis \& Pattisina, 1990; Fioroni et al., 1991; Gibbs \& Bryan, 1987). This last effect, denominated imposex is induced in several gastropod species both in the field and in laboratory studies at very low concentrations of TBT (imposex is initiated at less than $1 \mathrm{ng} / \mathrm{L}^{-1} \mathrm{TBT}$ in Nucella lapilus, and at 3-5ng/L-1 all females may be sterilized (Gibbs \& Bryan, 1994; concentrations of 1ng/ $\mathrm{L}^{-1}$ can induce imposex development in Thais clavigera, Horiguchi et al., 1995). This widely observed effects suggests that TBT and TPT may also act as endocrinal disruptors (Horiguchi et al., 1995, 1997a; Liu \& Suen, 1996; Mathiessen \& Gibbs, 1998; Oehlmann et al., 1996).

The detrimental effects of TBT and TPT upon non-target organisms led to restrictions to the use, first in France in 1982, where antifouling paintings containing TBT were prohibited for boats of less than 25m length (Sarradin et al., 1991; Waite et al., 1991), and then in many other countries, such as the United Kingdom (1987), United States (1988), Sweden, New Zealand (1989), Australia, Japan (1990) and Denmark (1991) (Champ \& Pugh, 1987; de Mora et al., 1989; Horiguchi et al., 1994; Kure \& Depledge, 1994; May et al., 1993; Stewart \& de Mora, 1990; Stuer-Lauridsen \& Dahl, 1995). Germany and Switzerland imposed restrictions also for freshwater environments (Champ, 1986). Recently the International Maritime Organization (IMO) recommended the global banning of organotin compounds as antifoulings by 2008 and the prohibition of new application in boats by 2003 (Champ, 1999; ten Hallers-Tjabbes, 1997). In Brazil, however, there is no legislation imposing restriction or addressing permissible levels, and up to very recently no investigations have been conducted to evaluate possible environmental impacts.

By the beginning of the last decade, restrictions imposed to the use of TBT and TPT in developed countries had led to the decrease in concentration of the parent compounds and decay products, both in waters and organisms. Recoveries were observed in oyster populations of Basin d'Arcachon (Alzieu, 1986) and in gastropods from coastal environments in United Kingdom (Evans et al., 1996; Tester et al., 1996; Tester \& Ellis, 1995). However, Kure \& Depledge (1994) reported that in Denmark, high concentrations could still be observed in filter feeders years after establishment of the restricted use.

Although TBT and TPT can be decomposed in the water column rather fast (half life time 7-15 days) (Foale, 1993), estimated half life of the order of 1 year for toxic sediments, to decades for anoxic sediments, are indicative of relatively high persistence in these environments, specially in the absence of oxygen (Dowson et al., 1996). In environments with high particulate loads where photochemical reactions are less active and transport to sediments may occur before extensive degradation in the water column takes place, sediments are a potential source of TBT and TPT even after the use has been interrupted (Dowson et al., 1993, 1996; Langston \& Pope, 1995; Sarradin et al., $1991,1994)$. The tendency to accumulate in sediments becomes evident from the levels of TBT reported for contaminated sediments that may range from $300 \mathrm{ng}^{-1} \mathrm{~g}^{-1}$ up to $1,000 \mathrm{ng}^{-1} \mathrm{~g}^{-1}$ or more, when compared to slightly contaminated sediments, where levels are in the range of 10 to 50ng.g-1 (Waite et al., 1991). Values as high as 4,500ng.g-1 TBT in sediments where detected in Thailand (Kan-Atireklap et al., 1997a) or 3,200ng.g-1 TBT in Hong-Kong (Ko et al., 1995).

After 1994, reports from several authors on the presence of TBT in higher organisms including cetaceans (Iwata et al., 1994; Kannan \& Falandysz, 1997; Tanabe, 1999), marine birds (Guruge et al., 1997a, 1997b) and humans (Kannan \& Falandysz, 1997; Takahashi et al., 1999) demonstrated that organotin compounds are likely to be transferred among different trophic levels. 
Little is known about the behavior of organotin compounds in tropical marine environments. Imposex has been observed in several species of gastropod on the coast of India (Cronia konkanensis - Vishwa-Kiran \& Anil, 1999); New Zealand (Lepsiella scobina, Thais orbita, Haustrum haustorium, Xymene ambiguus, Taron dubius, Cominella virgata, Amalda (Baryspira) australis - Stewart et al., 1992); Australia (Lepsiella vinosa - Nias et al., 1993; T. orbita - Foale, 1993); Thailand (Thais distinguenda, Thais bitubercularis, Morula musivaBech, 1999a, 1999b; Phalium bisulcatum, Distorsio reticularis, Murex occa, Murex trapa, Murex tribulus, Chicoreus capucinus, Thais gradata, Thais lacera, Babylonia areolata, Nassarius livescens, Nassarius stolatus, Hemifusus ternatanus, Voluma conchlidium, Cymbiola nobilis, Melo melo - Swennen et al., 1997); Indonesia (Thais kieneri, Thais savignyi, Vasum turbinellus - Evans et al., 1995); Malaysia (T. gradata, C. capucinus, T. clavigera, Thais jubilaea, T. bitubercularis - Tan, 1997, 1999) and Hong Kong (T. clavigera - Blackmore, 2000). In South America, imposex occurrence is reported in Chile (Chorus giganteus, Xanthochorus cassidiformis, Nucella crassilabrum - Gooding et al., 1999) and Brazil (Castro et al., 2000; Fernandez et al., 1998; Magalhães et al., 1997). Information on concentration in waters (Hashimoto et al., 1998; Malaca straits), sediments (Kan-Atireklap et al., 1997a - Thailand; Ko et al., 1995 - Hong Kong; Stewart \& de Mora, 1992 - Fiji Island; King et al., 1989 - New Zealand) and organisms (bivalves, Perna viridis - Kan-Atireklap et al., 1997b; Mytidus edulis and Aequipecten irradians - Guolan \& Yong, 1995; gastropods, T. clavigera, Thais tuberosa and Morula granulataLiu et al., 1997) are scarce, although reported levels specially in areas including intensive navigation and harbor installations have been high (over 1,000ng.g-1) and of the same order as those available for temperate climate areas (Morgan et al., 1998; Ruiz et al., 1998; Swennen et al., 1997; ten Hallers-Tjabbes et al., 1994). As for the effect on humans, although organotin compounds are considered extremely toxic, environmental routes of exposure are usually not considered very critical (Schweinfurth \& Günzel, 1987; Tsuda et al., 1995). However, the proved accumulation in filter feeders may be an important pathway to consumers (Guolan \& Yong, 1995).

Besides causing hormonal disruption, evidences that organotins seem to act upon the immune system of mammals (cetacean, rabbits, rats and sheep) (Dacasto et al., 1994a, 1994b; Kannan \& Falandysz, 1997; Kannan et al., 1997) and invertebrates (mollusks and tunicates) (Cima et al., 1995; Morcillo \& Porte, 1997) call for epidemiological investigations focused upon sensitive populations.

In Brazil, imposex in Thais haemastoma was first reported by Magalhães et al. (1997), in Santos Bay, São Paulo, by Fernandez et al. (1998), in Guanabara Bay, Rio de Janeiro and by Castro et al. (2000), in Fortaleza, Ceará.

The present work reports recent findings on possible TBT related effects in two of these areas of the Brazilian coast.

\section{Methodology}

The development of imposex in T. haemastoma was used as a tool to search for indications of biological stress derived from TBT and TPT in Guanabara Bay and in coastal areas of Fortaleza. The bioindicator was selected based on the following properties: (1) ubiquity along the Brazilian coast (Leal, 1984); (2) tendency to imposex development (Spence et al., 1990); (3) existing scientific evidences of imposex related to TBT and TPT for organisms of the same genus (T. clavigera and Thais bronni) (Horiguchi et al., 1997a; Liu \& Suen, 1996).

Figures 1 and 2 show the sampling stations from which 20 to 50 specimens of T. haemastoma were collected. Once in the laboratory, the specimens were narcotized by immersion in a $1: 1$ solution of local seawater and $\mathrm{MgCl}_{2}$ $7 \%$. Shell length was measured with the aid of a vernier calliper and after removing the soft parts from the shell, sex was determined based on the presence (female) or absence (male) of albumen and sperm ingestion glands (Figure 3) (Gibbs \& Bryan, 1987; Horiguchi et al., 1994; Spence et al., 1990). Penis length was also measured in males and imposexed females as in Axiak et al. (1995) e Stewart et al. (1992).

Imposex occurs at different levels which are related to TBT concentrations in water and in gastropod food; i.e., to the presence of this compound in the local environment. Therefore, different levels of alterations may be discriminated, ranging from apparently unaffected females to those showing male attributes. In the present work, four indicators of imposex were applied to the determine different level of imposex: (1)\% of imposexed females; (2) relative penis length index (RPLI); (3) relative penis size index (RPSI), and (4) vas deferens sequence index (VDSI). RPLI and RPSI were calculated by using the relations $\left(\left[\mathrm{C}_{\mathrm{FI}} / \mathrm{C}_{\mathrm{M}}\right] .100\right)$ and $\left(\left[\mathrm{C}_{\mathrm{FI}}{ }^{3 /}\right.\right.$ $\mathrm{C}_{\mathrm{M}^{3}}$.100) (Gibbs \& Bryan, 1987; Huet et al., 1996; Minchin \& Minchin, 1997), respectively, 
Location of Guanabara Bay area and reference station in the coast of Rio de Janeiro and monitoring stations along the coast of Fortaleza, Ceará State.
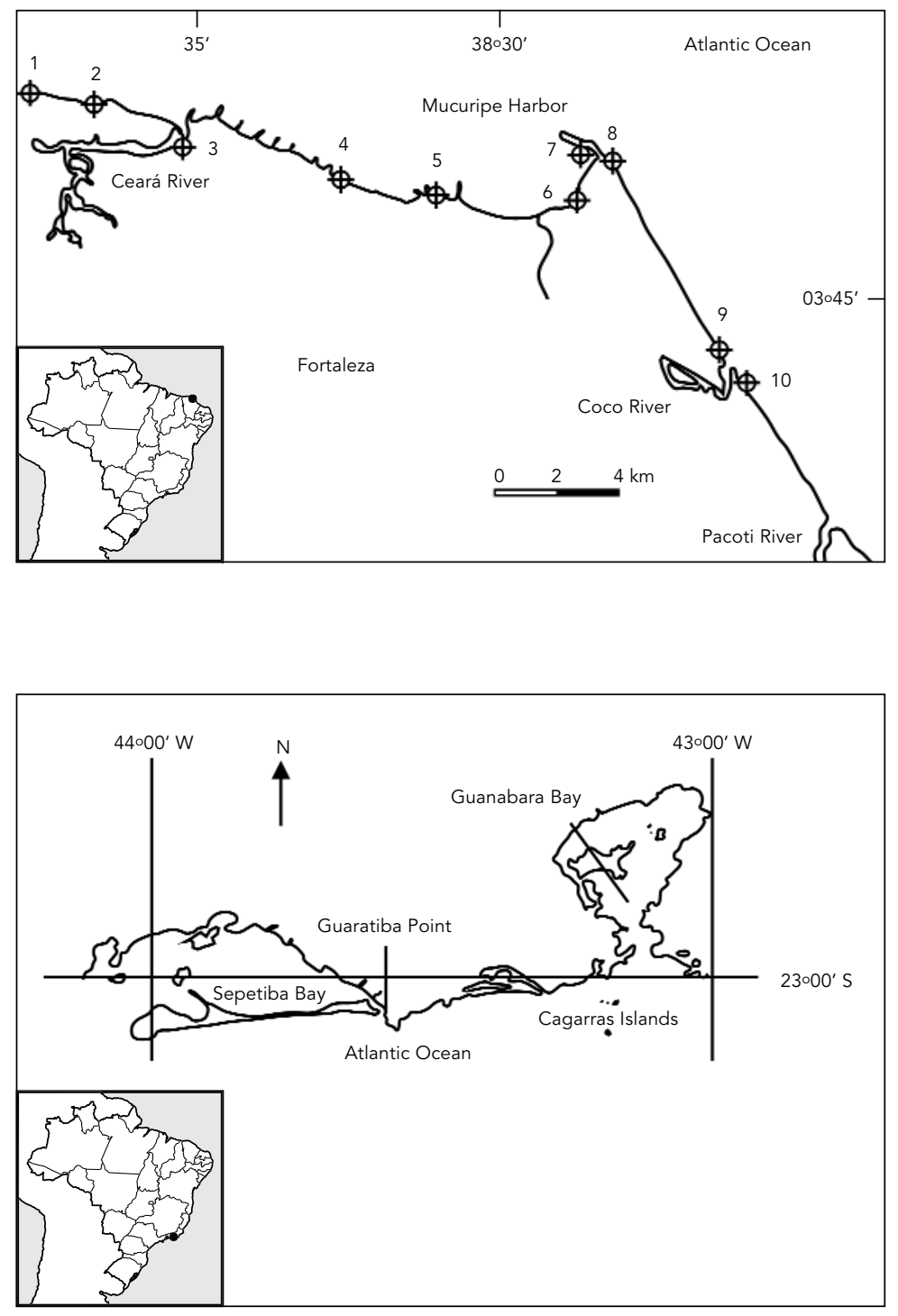

where $\mathrm{C}_{\mathrm{FI}}$ is the average penis length in imposexed females and $C_{M}$ is the average penis length in males at each sampled station.

The first index is a good indicator of imposex response at low environmental expositions, when not all females show male attributes (Curtis, 1994; Gibbs \& Bryan, 1994). The penis development indexes, RPLI and RPSI, are more adequate for medium (RPLI) or high (RPSI) imposex levels.

In this last situation, penis length of imposexed females approaches those of males, and the RPLI index becomes less effective in dis- criminating between different levels of alterations. VDSI is the only index that responds effectively over a broad range of imposex. It is useful in assessing the reproductive capacity of the studied population; populations with a mean VDSI above IV are comprised of sterile females, and show reduced reprodutive capacity (Gibbs \& Brian, 1994; Oehlmann et al., 1996, 1998; Stroben et al., 1995).

VDSI was obtained through two different approaches: (1) by using the scale of Gibbs (Gibbs \& Bryan, 1987), and (2) by using a modified scale of seven levels of imposex, developed by Fernandez et al. (1998). The development of a modified scale was required because of the difficulty to discriminating among initial stages of the Gibbs scale without using microscopy and histological analysis. The new scale provided an easy field method for assessing vas deferens sequence using only a magnifying glass. In this scale, level I of imposex was determined as in Solé et al. (1998) while discrimination between level III and IV was set according to Horiguchi et al. (1994). The other imposex levels were determined following the original scale of Gibbs. It should be emphasized that this scale was originally developed for N. lapilus. The same approach, however, could be adapted for other genera with little modifications (Fioroni et al., 1991; Horiguchi et al., 1994; Solé et al., 1998; Stewart et al., 1992; Stroben et al., 1995). The modified scale shows a slight tendency to underestimated results, however, there is in general, general agreement with the Gibbs scale (Table 1). The more detailed VDSI development scheme proposed by Fioroni et al. (1991) and Stroben et al. (1995), was tested, but histological analyses are required for its application.

\section{Results and discussion}

\section{Imposex in Guanabara Bay, Rio de Janeiro}

The results for the biomonitoring in Guanabara Bay are shown in Table 2. Figures 2 and 4 show a comparison of the actual distribution of T. haemastoma with that in the 1960s, and the geographic incidence of imposex, respectively. The potential sources of TBT and TPT are depicted in Figure 3.

As can be observed from Figure 2, the actual distribution of T. haemastoma differs significantly from that reported for the 1960s when the use of TBT in several areas of the globe was initiated. The species nowadays is absent in all stations at the inner areas of the bay (stations 
1, 2, 3 and 4) even though the past occurrence of T. haemastoma in stations 2, 3 and 4 have been reported by Leal (1984). In the sampling of August 1999, only empty shells were found in station 1.

Organisms were not found during the sampling campaigns of February and August 1999 in station 5 , located under the central part of the Rio-Niterói Bridge, and in station 9 (1998) located in a sewage contaminated area near a marina. However, while in all these areas $T$. haemastoma was absent, the mussell Perna perna, a common prey for the gastropod, was abundant, unless for the bridge site where mussel is frequently harvested for human consumption. The same feature was observed in stations 6 (presence of only one juvenile specimen), 8 (presence of only two young organisms) and 12, which are located near a harbor and two marinas. The presence of young organisms may indicate that a recolonization of the areas is possible, as reported by Spence et al. (1990) and Blackmore (2000) for species having planktonic larvae. It should be noted that stations 9 and 12 are in sites of restricted water circulation, a condition that favors the build up of critical TBT levels in the water (Gibbs \& Bryan, 1994; Horiguchi et al., 1994, 1997b; Nicholson et al., 1998).

Imposex indexes were generally high in the stations located inside Guanabara Bay (Figure 4). The relative abundance of imposexed females in a certain site is a tool for impact assessment when concentrations of TBT in water are relatively low and only a fraction of the females is masculinized (Curtis, 1994; Gibbs \& Bryan, 1994). For all sites inside Guanabara Bay $100 \%$ of the analyzed females showed some degree of sexual alteration, and only in four stations outside the bay, normal and less imposexed females were present (Ponta do Arpoador, Itacoatiara, Cagarras Island and the control station at Barra de Guaratiba) (Figure 4).

RPLI and RPSI levels are shown in Figure 4. Except for some stations (RPLI: 17b, 19 and 20; RPSI: 15, 17b, 18, 19 and 20) where due to the small penis size in the females, indexes could not be determined, all other stations inside Guanabara Bay showed measurable indexes. RPSI and RPLI values above 30 and 70, respectively, obtained for some inner sites of the bay have been considered high in other regions known as polluted by TBT. For instance, values ranging from 60.9 to 127.3 for RPLI and from 22.2 to 206.2 for RPSI were recorded in T. clavigera and T. bronni (Horiguchi et al., 1994, 1997b) from the most polluted sites in Japan, around Aburatsubo in the Miura Peninsula.
Figure 2

Map showing the sampling stations and main sources of TBT and TPT in Guanabara Bay.

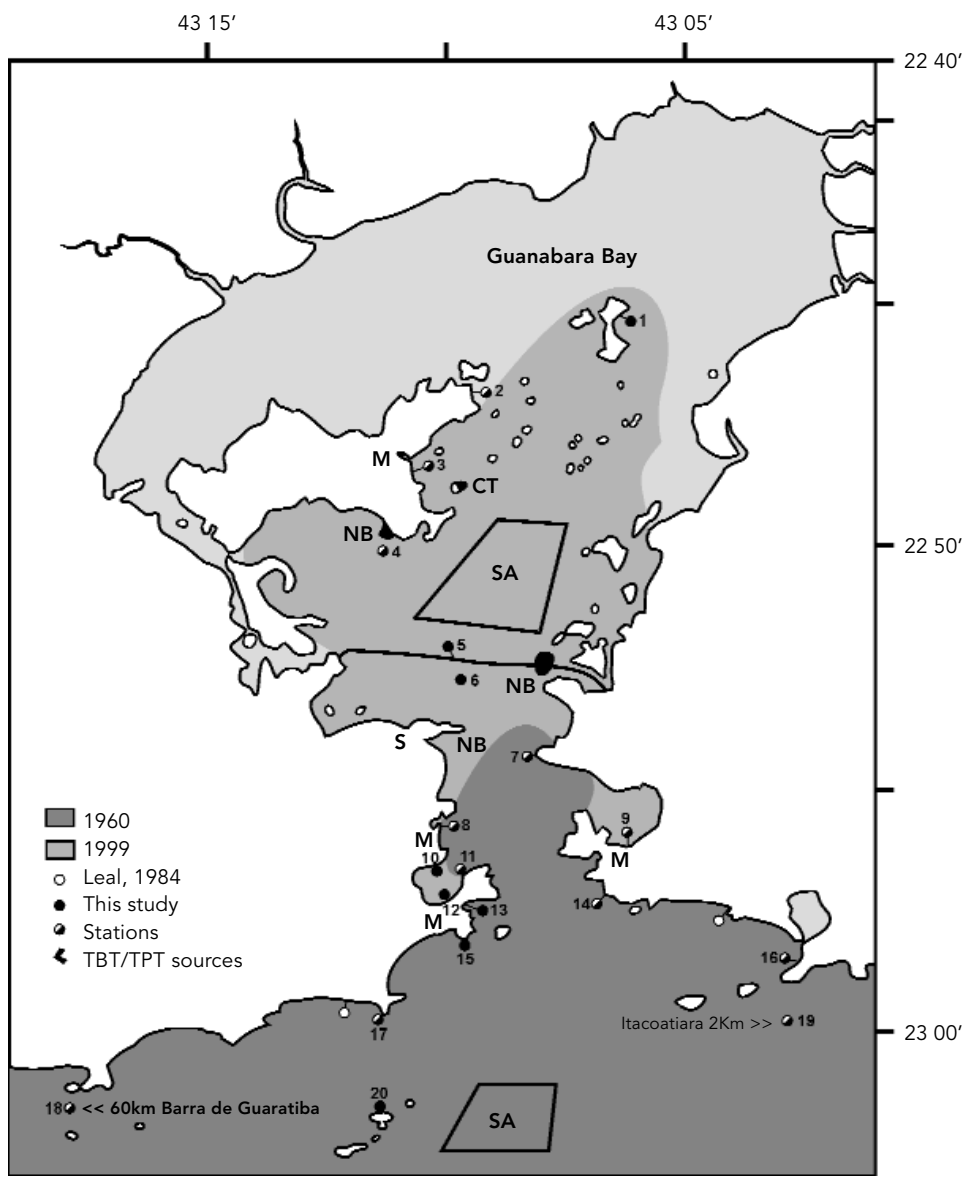

$\mathrm{M}=$ marine; $\mathrm{CT}=$ commercial terminal; $\mathrm{S}=$ shipyard; $\mathrm{NB}=$ naval base; $\mathrm{SA}=$ ship anchoring area. Comparison between the actual occurrence of T. haemastoma and the distribution observed in the 1960s in Guanabara Bay is also showed as shaded areas.

Values over 100 indicate that imposexed females mean penis lenghts (RPLI), or volumes (RPSI) are greater than those of males from the same locations. Nicholson et al. (1998) reported that values of RPSI in $N$. lapilus were in the range 37.9 to 44.8 near Sollun Voe, an oil tanker port, and Spence et al. (1990) recorded values as high as 48.3 to 81.7 in T. haemastoma collected from harbors and marinas in the Azores.

An increasing gradient in imposex intensity towards inner areas can be observed both in the western (RPLI from N.A. to 106.3 and RPSI from N.A. to 107.6 in stations $11,13,15,17,20$ ) and eastern (RPLI from N.A. to 107.6 and RPSI from N.A. to 125 in stations $7,14,16,19)$ sides of the bay entrance. Those gradients include all imposex levels so far detected in Guanabara Bay. 
A
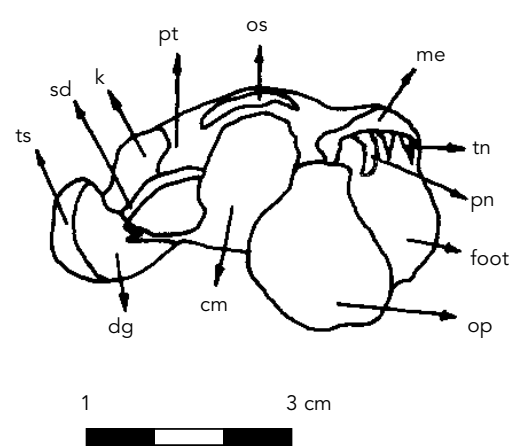

B

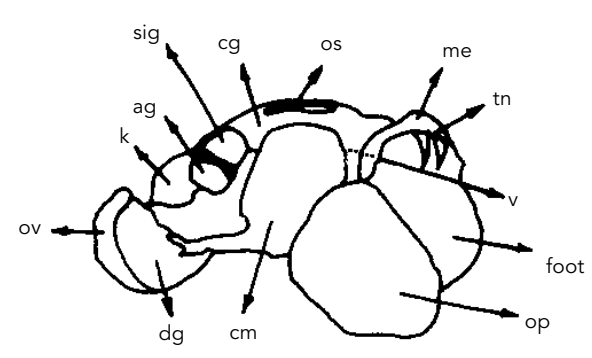

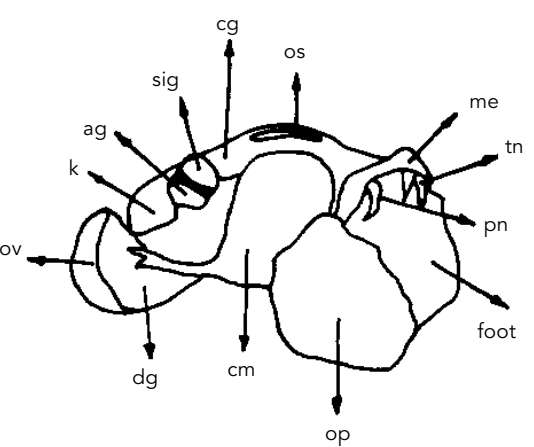

tn - tentacles; me - mantle edge; os - osphradium; cm - collumela muscle; op - operculum; dg - digestive gland;

k - kidney; pn - penis; ts - testicle; sd - spermatic duct; pr - prostate; v - vulva (inside mantle cavity); ov - ovary;

ag - albumem gland; sig-sperm ingesting gland; cg - capsule gland.

Table 1

Comparison between the Gibbs scale and the adapted scale for vas deferens sequence index (VDSI).

\begin{tabular}{lll}
\hline Gibbs scale & Characteristics of imposex development & Modified scale \\
\hline 0 & Normal Female & 0 \\
I & Beginning of penis formation (A), & I \\
& Beginning of vas deferens formation (G) & II \\
II & Formed penis, length $<2 \mathrm{~mm}$ & III (RPLIi < 0.5) \\
III & Formed penis, length $>2 \mathrm{~mm}$, distal vas deferens present (G) & IV (RPLli $>0.5)$ \\
IV & Completely developed vas deferens & V \\
V & Vulva blocked by growth of vas deferens tissues & VI \\
VI & Dark mass of aborted capsules in capsule gland & \\
\hline
\end{tabular}

RPLIi = Relative Penis Length Index of female $\mathrm{i}=\left[\mathrm{C}_{\mathrm{Fl}} / \mathrm{C}_{\mathrm{M}}\right]$ * 100 (adapted from Gibbs \& Bryan, 1987).

The penis length is a better tool to characterize the first and medium stages of imposex development than the penis volume, therefore, RPLI values seems to be more adequate for discriminating between stations than RPSI, in Guanabara Bay. Similar findings were reported by Horiguchi et al. (1994), in T.clavigera and $T$. bronni along the Japanese coast.

The observed VDSI values and existing imposex gradients (Figure 4) confirmed the observations given above. In stations 6 and 11 sterile organisms with VDSI levels V and VI were found. In station 6 in Boa Viagem, Niterói, only a female was found amongst 15 adults harvested during February 1999 while in August 1999 only a few young organisms were available for sampling. In station 11, organisms of VDSI V and VI were found in 1997 and in January 2000, only a single female amongst 18 adults was present showing VDSI of IV. The unbalanced sex distribution in those stations may result from selective extinction of females due to the blockage of capsule glands, a phenomenon observed in other regions and described by Spence et al. (1990), Nicholson et al. (1998) and Blackmore (2000).

Based on the results obtained for the several indexes given above, we inferred that three 
Results of biological monitoring in Guanabara Bay.

\begin{tabular}{|c|c|c|c|c|c|c|c|}
\hline Station & Date & Location & n (males/females) & $\%$ imposex & RPLI & RPSI & VDSI \\
\hline 1 & August 1999 & Paquetá Island (*) & NF & NA & NA & NA & NA \\
\hline 2 & March 1998 & Valente Inlet $\left(^{\star}\right)$ & NF & NA & NA & NA & NA \\
\hline 3 & March 1998 & Zumbi Beach $\left(^{\star}\right)$ & NF & NA & NA & NA & NA \\
\hline 4 & March 1998 & Matoso Point $\left({ }^{\star}\right)$ & NF & NA & NA & NA & NA \\
\hline $5 a$ & February 1999 & Rio-Niterói Bridge $\left(^{\star}\right)$ & NF & NA & NA & NA & NA \\
\hline $5 b$ & August 1999 & Rio-Niterói Bridge $\left(^{\star}\right)$ & NF & NA & NA & NA & NA \\
\hline 6 & February 1999 & Feiticeiras Rocks & 1 (NA) & NA & NA & NA & NA \\
\hline $7 a$ & February 1999 & Boa Viagem Island $(*)$ & $15(14 / 1)$ & 100.0 & 107.6 & 125.0 & V \\
\hline $7 b$ & August 1999 & Boa Viagem Island $\left(^{*}\right)$ & 10 (NA) & NA & NA & NA & NA \\
\hline 8 & September 1997 & Glória Marine $\left(^{*}\right)$ & $2(1 / 1)$ & NA & NA & NA & NA \\
\hline 9 & March 1998 & São Francisco Inlet $\left({ }^{\star}\right)$ & NF & NA & NA & NA & NA \\
\hline 10 & September 1997 & Flamengo Beach & $8(5 / 3)$ & 100.0 & 106.3 & 120.0 & IV \\
\hline $11 a$ & April 1997 & Urca, São João Fortress $\left(^{\star}\right)$ & $27(18 / 9)$ & 100.0 & 90.3 & 79.0 & IV \\
\hline $11 b$ & July 1997 & Urca, São João Fortress (*) & $29(15 / 14)$ & 100.0 & 90.8 & 75.0 & $\mathrm{~V}$ \\
\hline $11 c$ & January 2000 & Urca, São João Fortress $\left(^{\star}\right)$ & $18(17 / 1)$ & 100.0 & 81.6 & 54.4 & IV \\
\hline $11 x$ & January 2000 & Urca, São João Fortress, internal area & $21(9 / 12)$ & 100.0 & 21.8 & 1.1 & $|-| I \mid$ \\
\hline $12 a$ & April 1997 & Rio de Janeiro Yatch Club & NF & NA & NA & NA & NA \\
\hline $12 b$ & January 2000 & Rio de Janeiro Yatch Club & $1(1 / 0)$ & NA & NA & NA & NA \\
\hline 13 & May 1998 - March 2000 & Vermelha Beach & $188(120 / 68)$ & 100.0 & 44.0 & 13.0 & III \\
\hline 14 & July 1998 & Adão Beach $\left(^{\star}\right)$ & $17(12 / 5)$ & 100.0 & 83.1 & 57.0 & IV \\
\hline 15 & July 1997 & Leme Beach & $17(11 / 6)$ & 100.0 & 8.5 & $<0.1$ & I \\
\hline $16 a$ & July 1998 & Itaipú Point $\left(^{\star}\right)$ & $15(10 / 5)$ & 100.0 & 32.7 & 1.4 & II \\
\hline $16 b$ & July 1998 & Itaipú Point $\left(^{*}\right)$ & $17(11 / 6)$ & 100.0 & 37.6 & 13.0 & II \\
\hline $17 a$ & May - August 1998 & Arpoador Point $\left({ }^{\star}\right)$ & $26(16 / 10)$ & 30.0 & 44.1 & 8.6 & II \\
\hline $17 b$ & January 2000 & Arpoador Point $(*)$ & $20(11 / 9)$ & 22.2 & $<0.1$ & $<0.01$ & $|-| \mid$ \\
\hline 18 & May 1997 & Barra de Guaratiba Beach & $51(26 / 25)$ & 19.0 & 5.6 & $<0.1$ & 1 \\
\hline 19 & March 2000 & Itacoatiara Beach $\left(^{\star}\right)$ & $30(15 / 15)$ & 53.3 & $<0.1$ & $<0.01$ & $0-1$ \\
\hline 20 & April 2000 & Cagarras Islands & $27(12 / 15)$ & 40.0 & $<0.1$ & $<0.01$ & $0-1$ \\
\hline
\end{tabular}

$\mathrm{NF}=$ Animal not found; $\mathrm{NA}=$ Not analyzed; $\left({ }^{*}\right)=$ Animal reported before in this station;

$\mathrm{RPLI}=$ Relative penis length index; RPSI = Relative penis size index; VDSI = Vas deferens sequence index.

regions, with different degrees of impact exist in Guanabara Bay: (1) the region extending from the Rio-Niterói Bridge to the northern area of the bay (stations 1 to 4 ) where presently the bioindicator is not available. Here, at the present stage of knowledge, it is difficult to attribute the absence of organisms to TBT or TPT contamination because this region receives heavy loads of other pollutants derived from domestic and industrial sources; (2) the region between the Rio-Niterói Bridge and the mouth of the bay (stations 5 to 14) where high indexes of imposex and strong imposex gradients were found, and (3), regions outside of Guanabara Bay (stations 15 to 20) in which only organisms with low imposex levels were found, and lesser impact is to be expected.

The results of the two samplings in Arpoador (station 17) showed a wide range of vari- ability that can be ascribed to the difference in size and sexual development of the organisms available for sampling. This was the greatest variability observed in repeated sampling of the same station.

The water circulation pattern and the proximity to possible sources of TBT seem to be important factors controlling the degree of imposex in the studied area. This trend to higher imposex indexes (RPSI > 10; RPLI $>30$; VDSI $\geq$ II) with increasing boat traffic or anchoring and water stagnation is a typical feature of TBT contamination (Axiak et al., 1995; Smith \& McVeagh, 1991; Spence et al., 1990; Stewart et al., 1992) that has been used to map zones of influence in a regional (Minchin et al., 1996; Minchin \& Minchin, 1997) and national scale (Horiguchi et al., 1994, 1997b; ten HallersTjabbes et al., 1994, 1996). A few authors 
Intensity of imposex in Guanabara Bay as determined according to RPLI index.

Displayed area corresponds to the actual area where T. haemastoma is still found in the bay.

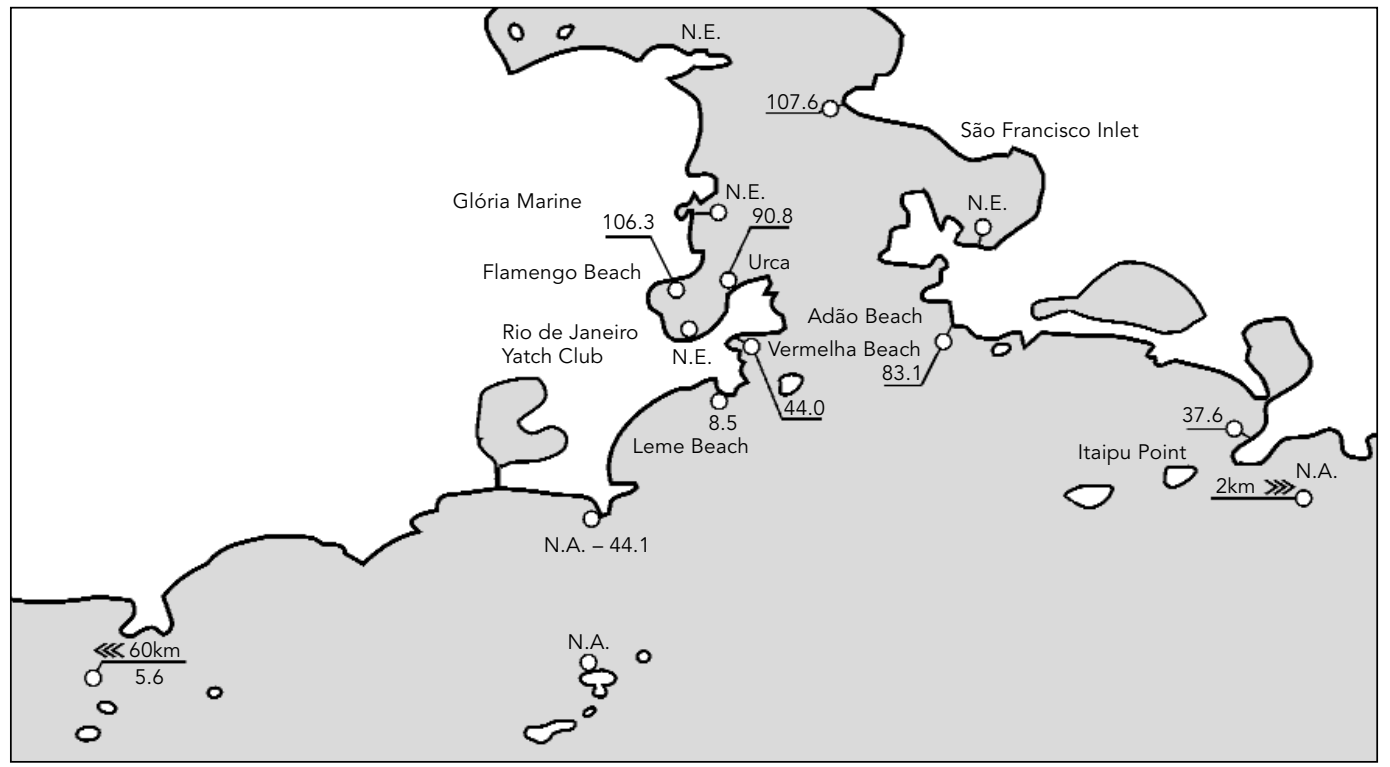

Figure $4 b$

Intensity of imposex in Guanabara Bay as determined according to RPSI index.

Displayed area corresponds to the actual area where T. haemastoma is still found in the bay.

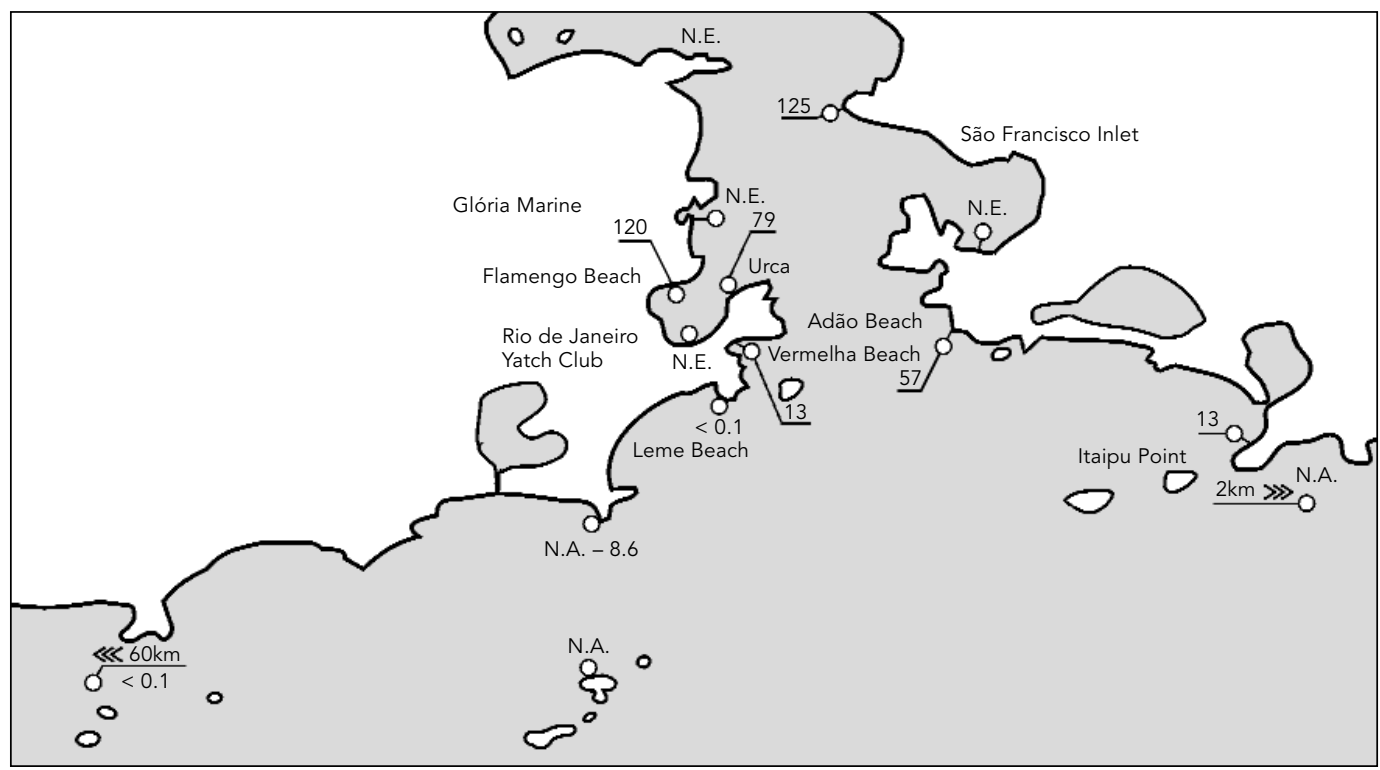


Intensity of imposex in Guanabara Bay as determined according to VDSI index.

Displayed area corresponds to the actual area where T. haemastoma is still found in the bay.

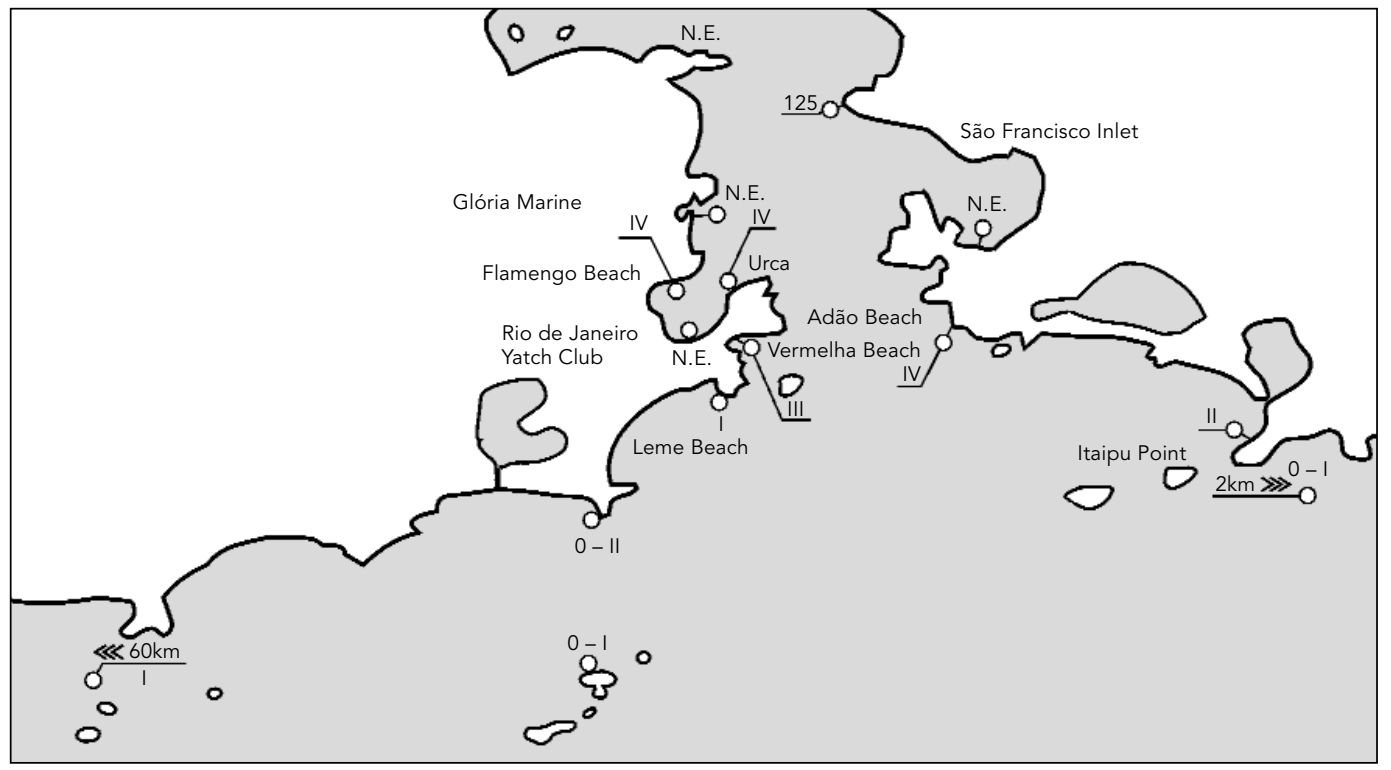

(Davies et al., 1987; Evans, 1999; Nicholson et al., 1998) based on experimental observations have proposed that TBT impact would be restricted to sites directly under influence of specific sources showing, therefore, little tendency to migrate over long distances from the input area. Our results seems to confirm this observation. In Guanabara Bay the actual absence of the organism in previously reported sites is an additional evidence of impact (Huet et al., 1996; Minchin \& Minchin, 1997; Smith, 1996) that may be derived from TBT, especially when mussels are abundant (Morcillo \& Porte, 1997).

\section{Imposex in the coast area of Fortaleza, Ceará}

Imposex was registered in several of the sampling sites (Figure 1 and Table 3 ) and the higher indexes were found in females collected from areas near the Mucuripe Harbor. In the Pacheco Beach and in Titanzinho, Caça e Pesca and Sabiaguaba, beaches where boat cruises are virtually absent, no imposex or related anomalies were observed. The absence of imposex in the last three beaches located east of Mucuripe Harbor is due to the water circulation in the region that prevents contamination predominantly flowing from east to west (Maia, 1998). In station 2 (Dois Coqueiros Beach) evidence of imposex in stage I (VDSI) was observed in females that showed a small protuberance as a first step towards penis development. Because in this initial stage, the penis dimensions cannot be measured, RPSI was not determined for this station, neither was it for Formosa and Poço da Draga, where females displayed similar alterations. In station 3 (Barra do Ceará), advanced stages of imposex were found with VDSI ranging between II and III, a RPLI of 31.9 and a RPSI of 3.2. In this area there is a small shipyard and boat cruising is intensive. In Mucuripe Beach (station 6), near Mucuripe Harbor and Mansa Beach (station 7), also close to the harbor, where boat traffic associated to fishing and tourism as well as large ship traffic are very intense, VDSI was V, except for a single female in Mansa Beach that had VDSI equal to IV. The values of the RPLI and RPSI obtained for both station 6 (RPLI 63.6 and RPSI 25.7) and station 7 (RPLI 82.8 and RPSI 61.7) are comparable to those found in Guanabara Bay and elsewhere, and support the conclusions drawn from the vas deferens index.

Contrary to the observations of Bryan et al. (1986) in N. lapillus whose populations had severely decreased prior to the establishment of restrictions to TBT use, populations of $T$. heamastoma in Fortaleza were apparently stable and abundant in all sampling sites. The intra- 
Table 3

Results of biological monitoring in Fortaleza, Ceará.

\begin{tabular}{|c|c|c|c|c|c|c|c|}
\hline Station & Date & Location & n (males/females) & $\%$ imposex & RPLI & RPSI & VDSI \\
\hline 1 & March 2000 & Pacheco Beach & $27 / 23$ & 0.0 & 0.0 & 0 & 0 \\
\hline 2 & March 2000 & Dois Coqueiros Beach & $20 / 30$ & 100.0 & $<0.1$ & $<0.01$ & $|-| \mid$ \\
\hline 3 & October 2000 & Barra do Ceará Beach & $15 / 35$ & 100.0 & 31.9 & 3.2 & III \\
\hline 4 & November 1999 & Formosa Beach & $26 / 24$ & 100.0 & $<0.1$ & $<0.01$ & I \\
\hline 5 & December 1999 & Poço da Draga Beach & $32 / 18$ & 100.0 & $<0.1$ & $<0.01$ & I \\
\hline 6 & September 1999 & Mucuripe Beach & $36 / 14$ & 100.0 & 63.6 & 25.7 & IV \\
\hline 7 & March 2000 & Mansa Beach & $32 / 18$ & 100.0 & 82.8 & 61.7 & V \\
\hline 8 & January 2000 & Titanzinho Beach & $25 / 25$ & 0.0 & 0.0 & 0.0 & 0 \\
\hline 9 & January 2000 & Caça e Pesca Beach & $22 / 28$ & 0.0 & 0.0 & 0.0 & 0 \\
\hline 10 & December 1999 & Sariguaba Beach & $20 / 30$ & 0.0 & 0.0 & 0.0 & 0 \\
\hline
\end{tabular}

$\mathrm{RPLI}=$ Relative penis length index; RPSI = Relative penis size index; VDSI = Vas deferens sequence index.

capsular development of $N$. lapillus (Bauchet, 1989; Feare, 1970) seems to favor population decline in polluted sites because organisms are directly exposed to the contaminant since the early stages of life. As T. haemastoma development presents a stage of planktonic larvae, areas can be re-colonized by organisms imported from uncontaminated sites (Spence et al., 1990) promoting constant provision of healthy individuals.

T. haemastoma spawning was observed even in sites where stage IV of VDSI occurred, both in Fortaleza and in Guanabara Bay. A similar observation was reported by Gibbs \& Bryan (1986), Fioroni et al. (1991) and Oehlmann et al. (1996) that concluded reproductive failure will only occur in organisms displaying VDSI above $\mathrm{V}$, a limit above which blockage of the female genitals initiates. In Mansa Beach, however, the majority of the sampled organisms showed VDSI V with penis and vas deferens completely formed and blocked genital cavity. In this case spawning was not observed, suggesting that affected females were unable to reproduce.

\section{Conclusions}

In the present investigation, sexual alterations leading to imposex in females of neogastropod T. Haemastoma were observed in Rio de Janeiro and in Ceará coastal areas. This reprodutive anomaly has been attributed to the presence of TBT and TPT in the water (Gibbs \& Bryan, 1994; Horiguchi et al., 1997a, 1997b; ten HallersTjabbes et al., 1994). Although concentration levels in water are not yet available for the ob- served sites, the distribution of imposex levels points towards a possible cause-effect relation with TBT and/or TPT.

The biomonitoring results for Guanabara Bay and Fortaleza show that higher imposex indexes are occurring in areas of harbor and marina activities, confirming the trend observed by other authors in several regions of the globe. Because Guanabara Bay is subjected to various sources of organic and inorganic pollutants, it is difficult to establish unambiguous cause-effect relationships. However, the actual absence of T. Haemastoma in areas where it was commonly found in the past, raises concern on the extension of possible effects of TBT contamination in the bay.

All sampled females from Guanabara Bay displayed some level of imposex. Differently, in Fortaleza some sites were unaffected and, possibly due to the lower level of contamination of the marine environment, no evidence of extinction were registered.

The wide distribution of T. haemastoma along the Brazilian coast makes the species a good candidate for large scale biological screening of "hot spots" of TBT and TPT pollution, although further laboratory and field studies are required to establish a quantitative relation between imposex level and concentration of TBT and/or TPT in the marine environment. 


\section{Acknowledgements}

The authors are grateful to Fundação de Amparo à Pesquisa do Estado do Rio de Janeiro for financial support and to L. Gebara, G. Telles, L. Bispo, P. Miyamoto, P. Nogueira, L. Varoveska, G. Uller, C. A. Meirelles and to Projeto Maqua/Universidade do Estado do Rio de Janeiro for the collaboration in the field work. L. P. Maia, from Departamento de Geologia, Universidade Federal do Ceará, kindly furnished information on coastal currents in Fortaleza. We also thank J. Oehlmann, M. Bech and M. Solé for very useful discussions about the development of this work.

\section{References}

ALZIEU, C., 1986. TBT detrimental effects in oyster culture in France - Evolution since antifouling paint regulation. In: Oceans 1986 International Organotin Symposium, Proceedings, v. 4, pp. 1130-1134. Washington, DC: Marine Technology Society.

ALZIEU, C.; SANJUAN, J.; DELTREIL, J. P. \& BOREL, M., 1986. Tin contamination in Arcachon bay: Effects in oyster shell anomalies. Marine Pollution Bulletin, 20:22-26.

ALZIEU, C.; SANJUAN, J.; MICHEL, P.; BOREL, M. \& DRENO, J. P., 1989. Monitoring and assessment of butyltins in Atlantic coastal waters. Marine Pollution Bulletin, 17:494-498.

AXIAK, V.; VELLA, A. J.; MICALLEF, D.; CHIRCOP, P. \& MINTOFF, B., 1995. Imposex in Hexaplex trunculus (Gastropoda: Muricidae): First results from biomonitoring of tributyltin contamination in the Mediterranean. Marine Biology, 121:685-691.

BACCI, E. \& GAGGI, C., 1989. Organotin compounds in harbor and marina waters from the northern Tyrrhenian sea. Marine Pollution Bulletin, 20: 290-292.

BAUCHET, P. A., 1989. A review of poecilogony in gastropods. Journal of Molluscan Studies, 55:67-78.

BECH, M., 1999a. Increasing levels of tributyltin-induced imposex in muricid gastropod at Phuket Island, Thailand. Applied Organometallic Chemistry, 13:1-6.

BECH, M., 1999b. Sensivity of different gastropod to tributyltin contamination. Phuket Marine Biological Center Special Publication, 19:1-6.

BLACKMORE, G., 2000. Imposex in Thais clavigera (neogastropoda) as an indicator of TBT (tributyltin) bioavailability in coastal waters of Hong Kong. Journal of Molluscan Studies, 66:1-8.

BRYAN, G. W.; GIBBS, P. E. \& HUMERSTONE, L. G., 1986. The decline of the gastropod Nucella lapillus around southwest England: Evidence for tributyltin from antifouling paints. Journal of the $\mathrm{Ma}$ rine Biological Association of the UK, 66:611-640.
CASTRO, I. B.; CASCON, H. M. \& FERNANDEZ, M. A., 2000. Imposex em Thais heamastoma (Linnaeus, 1767) (Mollusca:Gastropoda). Uma indicação da contaminação por organoestânicos na costa do Município de Fortaleza-Ceará-Brasil. Arquivos de Ciências do Mar, 33:51-56.

CHAMP, M. A., 1986. The science of the total environment. In: Oceans 1986 International Organotin Symposium, Proceedings, v. 4, pp. 1093-1100. Washington, DC: Marine Technology Society.

CHAMP, M. A., 1999. The need for the formation of an independent, international marine coatings board. Marine Pollution Bulletin, 38:239-246.

CHAMP, M. A. \& PUGH, W. L., 1987. Tributyltin antifouling paints: Introduction and overview. In: Oceans 1987 International Organotin Symposium, Proceedings, v. 4, pp. 1296-1308. Halifax: Marine Technology Society.

CIMA, F.; BALLARIN, L.; BRESSA, G. \& SABBADIN, A., 1995. Immunotoxicity of butyltins in tunicates. Applied Organometallic Chemistry, 9:567-572.

CURTIS, L. A., 1994. A decade long perspective on a bioindicator of pollution: Imposex on Ilyanassa obsoleta on cape henlopen, Delaware bay. Marine Environmental Research, 38:291-302.

DACASTO, M.; ABATE, O. \& NEBBIA, C., 1994b. Tossicità subacuta dell'acetato di trifenil-stagno (TPTA) nel coniglio: Osservazioni cliniche ed alterazioni ematologiche, ematochimiche ed enzimatiche. Schweizer Archiv für Tierheilkunde, 136:111-115.

DACASTO, M.; VALENZA, F; NEBBIA, C.; RE, G.; CORNAGLIA, E. \& SOFFIETTI, M. G., 1994a. Pathological findings in rabbits and sheep following the subacute administration of triphenyltin acetate. Veterinary and Human Toxicology, 36:300-304.

DAVIES, I. M.; BAILEY, S. K. \& MOORE, D. C., 1987. Tributyltin in scottish sea lochs, as indicated by degree of imposex in the dogwhelk, Nucella lapillus (L.). Marine Pollution Bulletin, 18:400-404.

DE MORA, S. J.; KING, N. G. \& MILLER, M. C., 1989. Tributyltin and total tin in marine sediments: 
Profiles and the apparent rate of TBT degradation. Environmental Technology Letters, 10:901908.

DIRYNDA, E., 1992. Incidence of abnormal shell thickening in the pacific oyster Crassostrea gigas in poole harbour (UK), subsequent to the 1987 TBT restrictions. Marine Pollution Bulletin, 24:156163.

DOWSON, P. H.; BUBB, J. M. \& LESTER, J. N., 1996. Persistence and degradation pathways of tributyltin in freshwater and estuarine sediments. Estuarine, Coastal and Shelf Science, 42:551-562.

DOWSON, P. H.; BUBB, J. M.; WILLIANS, T. P. \& LESTER, J. N., 1993. Degradation of tributyltin in freshwater and estuarine marina sediments. $\mathrm{Wa}$ ter Science and Technology, 28:133-137.

ELLIS, D. V. \& PATTISINA, L. A., 1990. Widespread neogastropod imposex: A biological indicator of global TBT contamination? Marine Pollution Bulletin, 21:248-253.

EVANS, S. M., 1999. Tributyltin pollution: The catastrophe that never happened. Marine Pollution Bulletin, 38:629-636.

EVANS, S. M.; DAWSON, M.; DAY, J.; FRID, C. L. J.; GILL, M. E.; PATTISINA, L. A. \& PORTER, J., 1995. Domestic waste and TBT pollution in coastal areas of Ambon island (eastern Indonesia). Marine Pollution Bulletin, 30:109-115.

EVANS, S. M.; EVANS, P. M. \& LEKSONO, T., 1996. Widespread recovery of dogwhelks, Nucella lapi$d u s$ (L.), from tributyltin contamination in the North Sea and Clyde Sea. Marine Pollution Bulletin, 32:263-269.

FAVORETO, R., 2000. Adaptação e Validação de Metodologia Analítica para a Determinação de Resíduos de Pesticidas Organoestânicos em Solo. Dissertação de Mestrado, Araraquara: Instituto de Química, Universidade Estadual Paulista.

FEARE, C. J., 1970. The reproductive cycle of the dog whelk Nucella lapillus. Proceedings of the Malacological Society of London, 39:125-137.

FENT, K., 1996. Ecotoxicology of organotin compounds. Critical Reviews in Toxicology, 26:1-117.

FERNANDEZ, M. A.; GEBARA, L.; TELLES, G.; BISPO, L. \& WAGENER, A. R., 1998. Imposex em Thais (stramonita) haemastoma na Baía da Guanabara, Rio de Janeiro: Possível impacto do uso de tributilestanho como antiincrustante. In: 5o Encontro Brasileiro de Ecotoxicologia, Anais, p. 45. Itajaí: Centro de Educação Superior em Ciências Tecnológicas, da Terra e do Mar, Universidade do Vale do Itajaí.

FIORONI, P.; OEHLMANN, J. \& STROBEN, E., 1991. The pseudohermaphoditism of prosobanchs: Morfological aspects. Zoollogischer Anzeiger, 286:1-26.

FOALE, S., 1993. An evaluation of the potential of gastropod imposex as a bioindicator of tributyltin pollution in Port Phillip Bay, Victoria. Marine Pollution Bulletin, 26:546-552.

GIBBS, P. E. \& BRYAN, G. W., 1986. Reprodutive failure in populations of the dog-whelk Nucella lapillus, ceased by imposex induced by tributyltin from antifouling paints. Journal of the Marine Biological Association of the UK, 66:767-777.

GIBBS, P. E. \& BRYAN, G. W., 1987. In: Oceans 1987 International Organotin Symposium, Proceedings, v. 4, pp. 1296-1308. Halifax: Marine Technology Society.

GIBBS, P. E. \& BRYAN, G. W., 1994. Biomonitoring of tributyltin (TBT) pollution using the imposex response of neogastropod molluscs. In: Biomonitoring of Coastal Waters and Estuaries (J. Kess \& M. Kramer, ed.), pp. 205-226, Boca Raton: CRC Press.

GOODING, M.; GALLARDO, C. \& LEBLANC, G., 1999. Imposex in three marine gastropod species in Chile and potential impact on muriciculture. $\mathrm{Ma}$ rine Pollution Bulletin, 38:1227-1231.

GUOLAN, H. \& YONG, W., 1995. Effects of tributyltin chroride on marine bivalve mussels. Water Research, 29:1877-1884.

GURUGE, K. S.; IWATA, H.; TANAKA, H. \& TANABE, S., 1997a. Butyltin accumulation in the liver and kidney of seabirds. Marine Environmental Research, 44:191-199.

GURUGE, K. S.; TANABE, S.; FUKUDA, M.; YAMAGISHI, S. \& TATSUKAWA, R., 1997b. Comparative distribution of butyltin compounds in commom cormorants (Phalacrocorax carbo) from Japan. Toxicological and Environmental Chemistry, 58:197-208.

HASHIMOTO, S.; WATANABE, M.; NODA, Y.; HAYASHI, T.; KURITA, Y.; TAKASU, Y. \& OTSUKI, A., 1998. Concentration and distribution of butyltin compounds in a heavy tanker route in the strait of Malacca and in Tokyo bay. Marine Environmental Research, 45:169-177.

HORIGUCHI, T.; IMAI, T.; CHO, H. S.; SHIRAISHI, H.; SHIBATA, Y.; MORITA, M. \& SHIMIZU, M., 1998. Acute toxicity of organotin compounds to the larvae of the rock shell, Thais clavigera, the disk abalone, Haliotis discus and the giant abalone, Haliotis madaka. Marine Environmental Research, 46:469-473.

HORIGUCHI, T.; SHIRAISHI, H.; SHIMIZU, M. \& MORITA, M., 1994. Imposex and organotin compounds in Thais clavigera e T. bronni in Japan. Journal of the Marine Biology Association of the $U K, 74: 651-669$.

HORIGUCHI, T.; SHIRAISHI, H.; SHIMIZU, M. \& MORITA, M., 1997a. Effects of triphenyltin chloride and five other organotin compounds on the development of imposex in the rock shell, Thais clavigera. Environmental Pollution, 95:85-91.

HORIGUCHI, T.; SHIRAISHI, H.; SHIMIZU, M. \& MORITA, M., 1997b. Imposex in sea snails, caused by organotin (tributyltin and triphenyltin) pollution in Japan: A survey. Applied Organometallic Chemistry, 11:451-455.

HORIGUCHI, T.; SHIRAISHI, H.; SHIMIZU, M.; YAMASAKI, S. \& MORITA, M., 1995. Imposex in japanese gastropods (Neogastropoda and Mesogastropoda): Effects of tributyltin and triphenyltin from antifouling paints. Marine Pollution Bulletin, 31:402-405.

HUET, M.; PAULET, Y. M. \& GLÉMAREC, M., 1996. Tributyltin (TBT) pollution in the coastal waters of West Brittany as indicated by imposex in $\mathrm{Nu}$ cella lapillus. Marine Environmental Research, 41:157-167.

IWATA, H.; TANABE, S.; MIYAZAKI, N. \& TATSUKAWA, R., 1994. Detection of butyltin compound residues 
in the blubber of marine mammals. Marine Pollution Bulletin, 28:607-612.

KAN-ATIREKLAP, S.; TANABE, S. \& SANGUANSIN, J., 1997a. Contamination by butyltin compounds in sediments from Thailand. Marine Pollution Bulletin, 34:894-899.

KAN-ATIREKLAP, S.; TANABE, S.; SANGUANSIN, J.; TABUCANON, M. S. \& HUNGSPREUGS, M., 1997b. Contamination by butyltin compounds and organochlorine residues in green mussel (Perna viridis, L.) from Thailand coastal waters. Environmental Pollution, 97:79-89.

KANNAN, K. \& FALANDYSZ, J., 1997. Butyltin residues in sediment, fish, fish-eating birds, harbour porpoise and human tissues from the polish coast of the Baltic sea. Marine Pollution Bulletin, 34:203207.

KANNAN, K.; SENTHILKUMAR, K.; LOGANATHAN, B. G.; TAKAHASHI, S.; ODELL, D. K. \& TANABE, S., 1997. Elevated accumulation of tributyltin and its breakdown products in bottlenose dolphins (Tursiops truncatus) found stranded along the U. S. Atlantic and gulf coasts. Environmental Science and Technology, 31:296-301.

KING, N.; MILLER, M. \& DE MORA, S., 1989. Tributyltin levels for sea water, sediment and selected marine species in coastal Northland and Auckland, New Zealand. New Zealand Journal of Marine and Freshwater Research, 23:287-294.

KO, M. M. C.; BRADLEY, G. C.; NELLER, A. H. \& BROOM, M. J., 1995. Tributyltin contamination of marine sediments of Hong Kong. Marine Pollution Bulletin, 31:249-253.

KURE, L. K. \& DEPLEDGE, M. H., 1994. Accumulation of organotin in Littorina littorea and Mya arenaria from Danish coastal waters. Environmental Pollution, 84:149-157.

LANGSTON, W. J. \& POPE, N. D., 1995. Determinants of TBT adsorption and desorption in estuarine sediments. Marine Pollution Bulletin, 31:32-43.

LEAL, J. H. N., 1984. Contribuição ao Conhecimento da Taxonomia em Thais (stramonita) haemastoma (Linnaeus, 1767) (Mollusca, Gastropoda, Muricidae). Dissertação de Mestrado, Rio de Janeiro: Departamento de Zoologia, Universidade Federal do Rio de Janeiro.

LIU, L. L.; CHEN, S. J.; PENG, W. Y. \& HUNG, J. J., 1997. Organotin concentrations in three intertidal neogastropods from the coastal waters of Taiwan. Environmental Pollution, 98:113-118.

LIU, L. L. \& SUEN, I. J., 1996. Organotins promoting the development of imposex in the oyster drill Thais clavigera. Journal of Fisheries Society of Taiwan, 23:149-154.

MAGALHÃES, C. A.; STRUCHI, P. P. \& ASBAHR, M., 1997. Evidências de imposex em populações de Stramonita haemastoma (Gastropoda: Prosobranchia) em áreas portuárias do Estado de São Paulo. In: Congresso Latino-Americano de Ciências do Mar, Anais, p. 282. Santos: Instituto Oceanográfico, Universidade de São Paulo/Associação Latino-americana de Investigadores em Ciências do Mar.

MAIA, L. P., 1998. Procesos Costeros y Balance Sedimentario a lo Largo de Fortaleza (NE-Brasil): Implicaciones para una Gestón Adecuada de la Zona
Litoral. Tesis de Doctorado, Barcelona: Universitad de Barcelona.

MATHISSEN, P. \& GIBBS, P. E., 1998. Critical appraisal of the evidence for tributyltin-mediated endocrine disruption in mollusks. Environmental Toxicology and Chemistry, 17:37-43.

MAY, L.; WHALEN, D. \& ENG, G., 1993. Interaction of triorganotin compounds with Chesapeake bay sediments and benthos. Applied Organometallic Chemistry, 7:437-441.

MENSINK, B. P.; VAN HATTUM, B.; ten HALLERSTJABBES, C. C.; EVERAARTS, J. M.; KRALT, H.; VETHAAK, A. D. \& BOON, J. P., 1997. Tributyltin Causes Imposex in the Common Whelk, Buccinum undatum - Mechanism and Occurrence. NIOZRapport 1997-6. Texel: Netherlands Institute for Sea Research.

MINCHIN, A. \& MINCHIN, D., 1997. Dispersal of TBT from a fishing port determined using the dogwhelk Nucella lapillus as an indicator. Environmental Technology, 18:1225-1234.

MINCHIN, D.; STROBEN, E.; OEHLMANN, J.; BAUER, B.; DUGGAN, C. B. \& KEATINGE, M., 1996. Biological indicators used to map organotin contamination in Cork harbour, Ireland. Marine Pollution Bulletin, 32:188-195.

MORCILLO, Y. \& PORTE, C., 1997. Interaction of tributyl-and triphenyltin with the microsomal monooxygenase system of molluscs and fish from the western Mediterranean. Aquatic Toxicology, 38:35-46.

MORGAN, E.; MURPHY, J. \& LYONS, R., 1998. Imposex in Nucella lapillus from TBT contamination in south-west Wales: A continuing problem around ports. Marine Pollution Bulletin, 36:840-843.

NIAS, D. J.; McKILLUP, S. C. \& EDYVANE, K. S., 1993. Imposex in Lepsiella vinosa from southern Australia. Marine Pollution Bulletin, 26:380-384.

NICHOLSON, G. J.; EVANS, S. M.; PALMER, N. \& SMITH, R., 1998. The value of imposex in the dogwhelk Nucella lapillus and the common whelk Buccinum undatum as indicators of TBT contamination. Invertebrate Reproduction and Development, 34:289-300.

OEHLMANN, J.; BAUER, B.; MINCHIN, D.; SCHULTEOEHLMANN, U.; FIORONI, P. \& MARKERT, B., 1998. Imposex in Nucella lapillus and intersex in Littorina littorea: Interspecific comparison of two TBT-induced effects and their geographical uniformity. Hydrobiologia, 378:199-213.

OEHLMANN, J.; FIORONI, P.; STROBEN, E. \& MARKERT, B., 1996. Tributyltin (TBT) effects on Ocinebrina aciculata (Gastropoda: Muricidae): Imposex development, sterilization, sex change and population decline. Science of the Total Environment, 188:205-223.

RUIZ, J. M.; QUINTELA, M. \& BARREIRO, R., 1998. Ubiquitous imposex and organotin bioaccumulation in gastropods Nucella lapillus from Galicia (NW Spain): A possible effect of nearshore shipping. Marine Ecology Progress Series, 164:237-244.

SARRADIN, P. M.; ASTRUC, A.; DESAUZIERS, V.; PINEL, R. \& ASTRUC, M., 1991. Butyltin pollution in surface sediments of Arcachon Bay after ten years of restricted use of TBT-based paints. Environmental Technology, 12:537-543. 
SARRADIN, P.-M.; ASTRUC, A.; SABRIER, R. \& ASTRUC, M., 1994. Survey of butyltin compounds in Arcachon Bay sediments. Marine Pollution Bulletin, 28:621-628.

SCHWEINFURTH, H. A. \& GÜNZEL, P., 1987. The tributyltins: Mammalian toxicity and risk evaluation for humans. In: Oceans 1987 International Organotin Symposium, Proceedings, v. 4, pp. 1421-1431. Halifax: Marine Technology Society.

SHORT, J. W. \& THROWER, F. D., 1986. Tri-n-butyltin caused mortality of chinook salmon, Oncorkinchus ishaurytscha, on transfer to TBT-treated marine net pen. In: Oceans 1986 International Organotin Symposium, Proceedings, v. 4, pp. 1202-1212, Washington, DC: Marine Technology Society.

SMITH, P. J., 1996. Selective decline in imposex levels in the dogwhelk Lepsiella scobina following a ban on the use of TBT antifoulants in New Zealand. Marine Pollution Bulletin, 32:362-365.

SMITH, P. J. \& McVEAGH, M., 1991. Widespread organotin pollution in New Zealand coastal waters as indicated by imposex in dogwhelks. $\mathrm{Ma}$ rine Pollution Bulletin, 22:409-413.

SOLÉ, M.; MORCILLO, Y. \& PORTE, C., 1998. Imposex in the commercial snail Bolinus brandaris in the northwestern Mediterranean. Environmental Pollution, 99:241-246.

SPENCE, S. K.; HAWKINS, S. J. \& SANTOS, R. S., 1990. The mollusc Thais haemastoma - An exhibitor of imposex and potential biological indicator of tributyltin pollution. Marine Ecology, 11:147-156.

STEWART, C. \& DE MORA, S. J., 1990. A review of the degradation of tri(n-butyl)tin in the marine environment. Environmental Technology, 11:565-570.

STEWART, C. \& DE MORA, S. J., 1992. Elevated tri(nbutyl)tin concentrations in shellfish and sediments from Suva harbour, Fiji. Applied Organometallic Chemistry,6:507-512.

STEWART, C.; DE MORA, S. J.; JONES, M. R. L. \& MILLER, M. C., 1992. Imposex in New Zealand neogastropods. Marine Pollution Bulletin, 24: 204-209.

STROBEN, E.; SCHULTE-OEHLMANN, U.; FIORONI, P. \& OEHLMANN, J., 1995. A comparative method for easy assessment of coastal TBT pollution by the degree of imposex in Prosobranch species. Haliotis, 24:1-12.

STUER-LAURIDSEN, F. \& DAHL, B., 1995. Source of organotin at a marine water/sediment interface A field study. Chemosphere, 30:831-845.

SWENNEN, C.; RUTTANADAKUL, S.; SINGH, H. R.; MENSINK, B. P. \& ten HALLERS-TJABBES, C. C., 1997. Imposex in sublittoral and littoral gastropods from the gulf of Thailand and strait of Malacca in relation to shipping. Environmental Technology, 18:1245-1254.
TAKAHASHI, S.; MUKAI, H.; TANABE, S.; SAKAYAMA, K.; MIYAZAKI, T. \& MASUNO, H., 1999. Butyltin residues in livers of humans and wild terrestrial mammals and in plastic products. Environmental Pollution, 106:213-218.

TAN, K. S., 1997. Imposex in three species of Thais from Singapore, with additional observations on T. clavigera (Küster) from Japan. Marine Pollution Bulletin, 34:577-581.

TAN, K. S., 1999. Imposex in Thais gradata and Chicoreus capucinus (Mollusca, Neogastropoda, Muricidae) from the straits of Johor: A case study using penis length, area and weight as measures of imposex severity. Marine Pollution Bulletin, 39:295-303.

TANABE, S., 1999. Butyltin contamination in marine mammals - A review. Marine Pollution Bulletin, 39:62-72.

ten HALLERS-TJABBES, C. C., 1997. Tributyltin and polices for antifouling. Environmental Technology, 18:1265-1268.

ten HALLERS-TJABBES, C.; EVERAARTS, J. M.; MENSINK, B. P. \& BOON, J. P., 1996. The decline of the North Sea whelk (Buccinum undatum l.) between 1970 and 1990: A natural or a man-induced event? Marine Ecology, 17:333-343.

ten HALLERS-TJABBES, C.; KEMP, J. F. \& BOON, J. P., 1994. Imposex in whelks (Buccinum undatum) from the open North Sea: Relation to shipping traffic intensities. Marine Pollution Bulletin, 28: 311-313.

TESTER, M. \& ELLIS, D., 1995. TBT controls and the recovery of whelks from imposex. Marine Pollution Bulletin,30:90-91.

TESTER, M.; ELLIS, D. V. \& THOMPSON, J. A. J., 1996. Neogastropod imposex for monitoring recovery from marine TBT contamination. Environmental Toxicology and Chemistry, 15:560-567.

TSUDA, T.; INOUE, T.; KOJIMA, M. \& AOKI, S., 1995. Daily intakes of tributyltin and triphenyltin compounds from meals. Journal of AOAC International, 78:941-943.

VISHWA-KIRAN, Y. \& ANIL, A. C., 1999. Record of imposex in Cronia konkanesis (Gastropoda, Muricidae) from Indian waters. Marine Environmental Research, 48:123-130.

WAITE, M. E.; WALDOCK, M. J.; THAIN, J. E.; SMITH, D. J. \& MILTON, S. M., 1991. Reductions in TBT concentrations in UK estuaries following legislation in 1986 and 1987. Marine Environmental Research, 32:89-111.

Submitted on 27 December 2000

Final version resubmitted on 1 October 2001

Approved on 10 December 2001 